\title{
Pendidikan Kewarganegaraan: usaha konkret untuk memperkuat multikulturalisme di Indonesia
}

\author{
Arif Prasetyo Wibowo dan Margi Wahono \\ Universitas Pendidikan Indonesia \\ Universitas Negeri Semarang \\ arifprasetyowibowo08@gmail.com
}

\begin{abstract}
Civic Education has a strategic role in strengthening multiculturalism in Indonesia. However, the contents of civic learning at the elementary level up to university level are showing lack of phenomenon that explores the multicultural values based on local wisdom (local genius). This research is a literature study by finding reference theories relevant to the cases or problems found. The reference theory obtained by method of literature study was presented as the foundation. It was found that: (1) The primordially knowledge, attitude and behavior of Indonesian society are kinds of things that impede Civics Education as a medium for strengthening multiculturalism in Indonesia; (2) Civic Education has great potential to become the foundation for multicultural strengthening in Indonesia with attention to innovation and development of the content, as well as the learning model. (3) Civic Education has a philosophical meaning as the foundation of ligature strength in the establishment of pluralism multicultural mentalities in order to realize national goals and nation's modernization without abandoning the local wisdom.
\end{abstract}

\section{Keywords: civics education, multicultural citizenship, local wisdom}

\section{Pendahuluan}

Negara Indonesia adalah negara kepulauan yang terdiri dari beraneka ragam suku bangsa dan adat istiadat, hal ini adalah karunia Tuhan yang wajib disyukuri. Kemajemukan yang miliki Indonesia sejatinya merupakan suatu kekuatan yang apabila persatuan dan kesatuan ini goyah dapat dijadikan kelemahan. Dewasa ini terdapat banyak sekali konflik yang terjadi dalam keseharian kehidupan bermasyarakat, berbangsa dan bernegara di Indonesia. Perang saudara antar suku, agama, dan kepentingan lainnya dapat mengganggu jalannya pembangunan nasional. Hal ini dibuktikan dengan adanya kerusuhan di Tanjung Balai, Medan, Sumatera Utara pada Tanggal 29 Juli 2016 yang mengandung unsur SARA (Suku, Agama, Ras dan Antar golongan) sehingga menodai kerukunan antar umat beragama dalam bingkai Negara Kesatuan Republik Indonesia (Tempo, 2016). Ancaman internal yang menimbulkan konflik di masyarakat yang bersifat komunal dalam keberagaman masyarakat indonesia sejatinya telah diidentifikasi oleh Departemen Pertahanan Republik Indonesia bahwa Indonesia menempatkan isu-isu ideologi, politik, ekonomi, sosial budaya, teknologi dan informasi kedalam lingkup pertahanan negara berdimensi nirmiliter (2008, p. 7). Konflik horizontal yang terjadi di masyarakat merupakan signal kuat yang harus diwaspadai oleh pemerintah dan seluruh elemen warga negara sebagai bentuk ancaman Devide et Impera gaya baru dalam menghancurkan persatuan dan kesatuan Negara Republik Indonesia. 
Sebagai upaya untuk mempercepat tercapainya tujuan nasional sesuai yang termaktub dalam Pembukaan UndangUndang Dasar Negara Republik Indonesia Tahun 1945. Pada masa pemerintahan Presiden Joko Widodo dan Wakil Presiden Jusuf Kalla mengeluarkan arahan kebijakan yang juga menjadi visi dan misi dari integrasi pembangunan negara ke depan. Hal ini diterangkan oleh Kementerian Pertahanan (2015, p. 36) yakni terwujudnya Indonesia yang berdaulat, mandiri, dan berkepribadian berlandaskan gotong royong yang dijabarkan melalui tujuh misi pembangunan dan sembilan agenda prioritas atau yang lebih dikenal dengan sebutan NAWACITA.

Adapun salah satu poin yang merupakan perwujudan dalam upaya percepatan pembangunan nasional ini diantaranya adalah dengan melakukan revolusi karakter bangsa melalui kebijakan penataan kembali kurikulum pendidikan nasional dengan mengedepankan aspek Pendidikan Kewarganegaraan (Civic Education) yang menempatkan secara proporsional aspek pendidikan, seperti: pengajaran sejarah pembentukan bangsa, nilai-nilai patriotisme dan cinta tanah air, semangat bela negara dan budi pekerti di dalam kurikulum pendidikan Indonesia. Berdasarkan hasil penelitian terdahulu yang dilakukan oleh Santoso, Almuchtar, dan Abdulkarim (2015, p. 108) menunjukkan bahwa kelemahan Pendidikan Kewarganegaraan di Indonesia ada pada sisi pengajaran yang bersifat monoton tidak inovatif (overload and overlapping content) dan lebih menitik beratkan hanya pada kognitif, sedangkan afektif dan psikomotorik ditiadakan serta tidak dimasukan pada ujian nasional

Dari berbagai permasalahan yang terjadi di Indonesia terkait multikultural pluralisme tersebut, pendidikan kewarganegaraan dapat menjadi salah satu solusi jitu sebagai sarana dalam mempersiapkan warga negara yang baik di tengah kompleksitas keberagaman yang berada di Indonesia. Yang dikarenakan Pendidikan Kewarganegaraan memiliki makna filosofis sebagai fondasi kekuatan ligatur dalam pembentukan mental multikultural pluralisme guna mewujudkan cita-cita nasional serta pemodernan bangsa dan negara tanpa meninggalkan kearifan lokal yang telah diajarkan para leluhur sejak dulu.

\section{Metode}

Pendekatan penelitian ini adalah kualitatif dengan sumber data pertama, sumber bahan cetak (kepustakaan), meliputi buku, jurnal, makalah dan literatur hasil penelitian tentang Pendidikan Kewarganegaraan. Kedua, sumber data berupa dokumen analisis yang meliputi hasil dokumen-dokumen kenegaraan tentang kurikulum pendidikan kewarganegaraan sekolah menengah atas dari tahun 1975-2013.

Teknik pengumpulan data dan informasi yang digunakan adalah teknik pengumpulan data kualitatif yang meliputi studi dokumentasi, dan studi pustaka. Sementara itu proses analisis data yang digunakan peneliti adalah reduksi data, display data, verifikasi dan penarikan kesimpulan (Miles \& Huberman, 1992).

\section{Hasil dan Pembahasan}

Perkembangan mata pelajaran Pendidikan Kewarganegaraan (PKn) di Indonesia memiliki sejarah panjang dalam peranannya mempersiapkan warga negara yang baik sesuai dengan hak dan kewajibannya. PKn juga telah banyak mengalami pergantian nama dan kurikulum selama enam dekade sejak awal berdirinya sebagai salah satu bidang studi tahun 1947 hingga saat ini. Menurut Nuh "Tidak ada 
kurikulum yang abadi, kurikulum berubah karena perubahan zaman, bukan karena kurikulum sekarang yang jelek atau salah. Sudah benar itu di zamannya. Tapi zaman berubah dan kita harus ikut berubah" (Santoso et al., 2015, p. 86). Pengembangan serta evaluasi kurikulum pendidikan kewarganegaraan di Indonesia memiliki kekhasan masing-masing dalam setiap pergantian konten pada masanya, jadi tidak ada kurikulum yang abadi.

Konsep kurikulum berkembang sejalan dengan perkembangan teori dan praktik pendidikan serta bervariasi sesuai dengan aliran atau teori pendidikan yang dianut oleh setiap negara. Kurikulum merupakan program pendidikan yang disediakan oleh lembaga pendidikan bagi kegiatan belajar, sehingga mendorong perkembangan dan pertumbuhannya sesuai dengan tujuan pendidikan yang telah ditetapkan (Madjid, 2014, p. 1). Perkembangan dan pertumbuhan suatu kurikulum dalam sistem pendidikan memiliki sifat yang dinamis, sehingga dalam pembentukannya disesuaikan dengan kebutuhan pada masa penerapan praktik kurikulum tersebut.

Hal ini yang terjadi pula pada mata pelajaran PKn di Indonesia yang diantaranya adalah istilah Civics secara formal tidak dijumpai dalam kurikulum tahun 1957 maupun kurikulum tahun 1946. Namun secara materiel dalam kurikulum SMP dan SMA tahun 1957 terdapat mata pelajaran Tata Negara dan Tata Hukum, dan dalam kurikulum 1946 terdapat mata pelajaran Pengetahuan Umum yang di dalamnya memasukan pengetahuan mengenai pemerintahan (Winataputra, 2012, p. 3).

Secara historis-epistemologi dan historispedagogis menurut Dept. P\&K (1962) Pendidikan Kewarganegaraan sebagai program kurikuler dimulai dengan diintroduksikannya mata pelajaran Civics dalam Kurikulum SMA tahun 1962 yang berisikan materi tentang pemerintahan Indonesia berdasarkan Undang-Undang Dasar Negara Republik Indonesia Tahun 1945 (Winataputra, 2012, p. 3). Selanjutnya Somantri (1969, p. 7)menjelaskan pada saat itu mata pelajaran Civics atau Kewarganegaraan pada dasarnya berisikan pengalaman belajar yang digali dan dipilih dari disiplin ilmu sejarah, geografi, ekonomi, dan politik, pidato-pidato presiden, deklarasi Hak Asasi Manusia, dan pengetahuan tentang Perserikatan Bangsa-Bangsa”.

Dari penjelasan tersebut, dapat ditarik kesimpulan mengenai fokus kajian pada kurikulum pendidikan moral tahun 19451964 berfokus pada pembahasan mengenai pengetahuan umum yang di dalamnya digali dan dipilih dari mata pelajaran sejarah, geografi, ekonomi, dan politik yang berkaitan dengan pelajaran Tata Negara dan Tata Hukum.

Pada tahun 1968 sampai 1969 penggunaan istilah Civics dan Pendidikan Kewargaan Negara digunakan secara bertukar-pakai (interchangeably). Misalnya dalam kurikulum SD 1968 digunakan istilah Pendidikan Kewargaan Negara yang dipakai sebagai nama mata pelajaran, yang di dalamnya tercakup sejarah Indonesia, geografi Indonesia, dan "civics" (diterjemahkan sebagai pengetahuan kewargaan negara). Di dalam kurikulum SMP 1968 digunakan istilah Pendidikan Kewargaan Negara yang berisikan sejarah Indonesia dan Konstitusi termasuk UndangUndang Dasar Negara Republik Indonesia Tahun 1945.

Sedangkan di dalam kurikulum SMA terdapat mata pelajaran Kewargaan Negara 
yang berisikan materi, terutama yang berkenaan dengan Undang-Undang Dasar Negara Republik Indonesia Tahun 1945. Sementara itu di dalam Kurikulum SPG 1969 mata pelajaran Pendidikan Kewargaan Negara isinya terutama berkenaan dengan sejarah Indonesia, Konstitusi, pengetahuan kemasyarakatan dan Hak Asasi Manusia (Winataputra, 2012, p. 3).

Pada masa Kurikulum 1973, kurikulum Civic Education (Pendidikan Kewargaan Negara) di dalam Kurikulum Proyek Perintis Sekolah Pembangunan digunakan beberapa istilah, yakni Pendidikan Kewargaan Negara, Studi Sosial, "Civics" dan Hukum. Untuk sekolah dasar 8 tahun pada Proyek Perintis Sekolah Pembangunan digunakan istilah Pendidikan Kewargaan Negara yang merupakan mata pelajaran Ilmu Pengetahuan Sosial terpadu atau identik dengan integrated social studies di Amerika. Di sini istilah Pendidikan Kewargaan Negara kelihatannya diartikan sama dengan Pendidikan Ilmu Pengetahuan Sosial. Di sekolah menengah pertama 4 tahun digunakan istilah Studi Sosial sebagai pengajaran Ilmu Pengetahuan Sosial yang terpadu untuk semua kelas dan pengajaran IPS yang terpisah-pisah dalam bentuk pengajaran geografi, sejarah, dan ekonomi sebagai program major pada jurusan Ilmu Pengetahuan Sosial. Selain itu juga terdapat mata pelajaran Pendidikan Kewargaan Negara sebagai mata pelajaran inti yang harus ditempuh oleh semua siswa. Sedangkan mata pelajaran Civics dan Hukum diberikan sebagai mata pelajaran major pada jurusan Ilmu Pengetahuan Sosial (Winataputra, 2012, p. 4).

Dalam Kurikulum 1975 istilah Pendidikan Kewargaan Negara diubah menjadi Pendidikan Moral Pancasila atau yang lebih dikenal dengan sebutan PMP yang berisikan materi Pancasila sebagaimana diuraikan dalam Pedoman Penghayatan dan Pengamalan Pancasila atau P4. Perubahan ini sejalan dengan misi pendidikan yang diamanatkan oleh Tap. MPR II/MPR/1973 tentang Pedoman Penghayatan dan Pengamalan Pancasila. Selanjutnya mata pelajaran Pendidikan Moral Pancasila ini merupakan mata pelajaran wajib untuk SD, SMP, SMA, SPG dan Sekolah Kejuruan. Ruang lingkup materi pembahasan secara keseluruhan mata pelajaran ini diantaranya adalah civics, sejarah kebangsaan, kejadian setelah Indonesia merdeka, UUD 1945, masing-masing sila Pancasila, pesan pentingnya pembangunan (seperti rencana pembangunan lima tahun dan Garis Besar Haluan Negara) bagi bangsa Indonesia, doktrin kenegaraan yang spesifik, membahas persoalan moral dan sebagainya, visi misinya berorientasi pada value inculcation dengan muatan nilai-nilai Pancasila dan UUD 1945 (Santoso et al., 2015, pp. 89-90).

Perkembangan Kurikulum pada tahun 1984 membuat Pemerintah memberlakukan Undang-Undang Nomor 2 Tahun 1989 tentang Sistem Pendidikan Nasional yang menggariskan adanya Pendidikan Pancasila dan Pendidikan Kewarganegaraan sebagai bahan kajian wajib kurikulum semua jalur, jenis dan jenjang pendidikan (Pasal 39) pada mata pelajaran Pendidikan Moral Pancasila, Kurikulum Pendidikan Dasar dan Sekolah Menengah 1994 mengakomodasikan misi baru pendidikan tersebut dengan memperkenalkan mata pelajaran Pendidikan Pancasila dan Kewarganegaraan atau PPKn (Winataputra, 2012, p. 4). Ruang lingkup materi dalam pembahasan mata pelajaran Pendidikan Moral Pancasila ini diantaranya adalah mengenai Hak Asasi Manusia, asas dan makna keadilan, UUD 1945, lembaga- 
lembaga negara, badan peradilan, kemerdekaan Indonesia, kerja sama internasional, dan kajian terhadap Pancasila itu sendiri (Santoso et al., 2015, pp. 89-90).

Berbeda dengan kurikulum sebelumnya, Kurikulum PPKn 1994 pengorganisasian materi dilakukan bukan atas dasar rumusan butir-butir nilai Pedoman Penghayatan dan Pengamalan Pancasila (P4), tetapi atas dasar konsep nilai yang diambil dari inti P4 dan sumber resmi lainnya yang ditata dengan menggunakan pendekatan spiral meluas atau spiral of concept development (Winataputra, 2012, p. 4) . Pendekatan ini mengartikulasikan sila-sila Pancasila dengan jabaran nilainya untuk setiap jenjang pendidikan dan kelas serta catur wulan dalam setiap kelas.

Sehingga materi pembahasan dalam PPKn ini memiliki ruang lingkup pertama, nilai, moral dan norma serta perilaku yang diharapkan terwujud dalam kehidupan bermasyarakat, berbangsa dan bernegara sebagaimana dimaksud dalam P4. Kedua, Kehidupan ideologi politik ekonomi, sosial, budaya, pertahanan, dan keamanan serta perkembangan ilmu pengetahuan dan teknologi dalam wadah kesatuan negara kesatuan Republik Indonesia yang berdasarkan Pancasila dan UUD 1945 (Santoso et al., 2015, pp. 89-90).

Hal ini dikarenakan dalam kurikulum 1994 untuk PPKn diartikan sebagai mata pelajaran yang digunakan sebagai wahana untuk mengembangkan dan melestarikan nilai luhur dan moral yang berakar pada budaya bangsa Indonesia. Kurikulum 1994 lebih mengarahkan peserta didik untuk menguasai materi pengetahuan. Materi pengetahuan diberikan pada peserta didik sesuai dengan tujuan-tujuan yang telah ditetapkan sebelumnya. Metode belajar di kelas yang terutama digunakan adalah ceramah dan tanya jawab (Budimansyah, 2010).

Berdasarkan Peraturan Pemerintah No. 25 Tahun 2000 maka Pemerintah melalui Departemen Pendidikan Nasional melakukan penyusunan standar nasional untuk seluruh mata pelajaran yang ada di Indonesia, adapun komponen-komponen yang disusun oleh pemerintah tersebut adalah (1) standar kompetensi, (2) kompetensi dasar, (3) materi pokok, dan (4) indikator pencapaian. Dengan dikeluarkannya Peraturan Pemerintah tersebut, maka terjadi pergantian nama dan kurikulum juga terhadap mata pelajaran yang semula Pendidikan Pancasila dan Kewarganegaraan (PPKn) menjadi Pendidikan Kewarganegaraan (PKn) dengan Kurikulum Berbasis Kompetensi atau yang lebih dikenal dengan sebutan KBK pada tahun 2004. Materi pembahasan dalam mata pelajaran Pendidikan Kewarganegaraan ini memiliki ruang lingkup mengenai persatuan bangsa dan negara, Nilai dan norma (agama, kesusilaan, kesopanan dan hukum), Hak Asasi Manusia, Kebutuhan hidup warga negara, Kekuasaan dan politik, masyarakat demokratis, Pancasila dan konstitusi negara, globalisasi; namun materi ini mengusung misi pendidikan nilai dan moral (Santoso et al., 2015)

Proses pengembangan Kurikulum Berbasis Kompetensi ini menggunakan asumsi bahwa siswa yang akan belajar telah memiliki pengetahuan dan keterampilan awal yang dibutuhkan untuk menguasai kompetensi tertentu. Oleh karenanya pengembangan kurikulum 2004 memperhatikan prinsip-prinsip berikut; (1) berorientasi pada pencapaian hasil dan dampaknya (outcome oriented), (2) berbasis pada Standard Kompetensi dan Kompetensi Dasar, (3) Bertolak dari Kompetensi Lulusan, 
(4) Memperhatikan prinsip pengembangan kurikulum yang terdiferensiasi, mengembangkan aspek belajar secara utuh dan menyeluruh (holistik), (6) menerapkan prinsip ketuntasan belajar (mastery learning) (Budimansyah \& Suryadi, 2008, p. 14)

Pada kurikulum tahun 2006 ini mata pelajaran Pendidikan Kewarganegaraan (PKn) memiliki tujuan agar peserta didik memiliki kemampuan; (1) berpikir kritis, rasional dan kreatif dalam menanggapi isu kewarganegaraan, (2) berpartisipasi secara aktif dan bertanggungjawab, bertindak secara cerdas dalam kegiatan bermasyarakat, berbangsa, dan bernegara, serta anti korupsi, (3) berkembang secara positif dan demokratis untuk membentuk diri berdasarkan karakterkarakter masyarakat Indonesia agar dapat hidup bersama-sama dengan bangsa lain, (4) Berinteraksi dengan bangsa-bangsa lain dalam percaturan dunia secara langsung atau tidak langsung dengan memanfaatkan teknologi informasi dan komunikasi (Budimansyah, 2010, pp. 121-122). Kurikulum 2013 merupakan kurikulum terbaru yang digunakan dalam sistem pendidikan di Indonesia saat ini. Kurikulum 2013 memiliki perbedaan dengan kurikulum sebelumnya, yakni Kurikulum Berbasis Kompetensi (KBK) dan Kurikulum Tingkat Satuan Pendidikan (KTSP) yang sudah penulis jelaskan secara singkat di atas. Perubahan konsep dalam sistem Kurikulum 2013 ini terdapat pada perubahan Standar Kompetensi Kelulusan (SKL), perubahan struktur kurikulum, pencapaian kompetensi siswa yang disesuaikan dengan kebutuhan Abad ke-21, serta perubahan pembelajaran yang menggunakan pendekatan saintifik.

Secara yuridis formal Kurikulum 2013 berpijak pada Undang-Undang Sistem Pendidikan Nasional Nomor 20 Tahun 2003, namun dalam pelaksanaannya didasarkan pada Peraturan Pemerintah Nomor 32 Tahun 2013 tentang Perubahan atas Peraturan Pemerintah Nomor 19 Tahun 2005 tentang Standar Nasional Pendidikan. Perubahan kurikulum tersebut berdampak pula terhadap mata pelajaran Pendidikan Kewarganegaraan di Indonesia, yang semula menggunakan istilah Pendidikan Kewarganegaraan atau yang lebih dikenal dengan sebutan PKn berubah kembali menjadi Pendidikan Pancasila dan Kewarganegaraan atau yang lebih dikenal dengan sebutan PPKn.

Berdasarkan hasil penelitian yang dilakukan oleh Setiawati (2016, p. 70) bahwa perubahan nomenklatur didasarkan pada sejumlah masukan penyempurnaan pembelajaran PKn menjadi PPKn yang mengemuka dalam lima tahun terakhir, antara lain: (1) secara substansial, PKn terasa lebih dominan bermuatan ketatanegaraan sehingga muatan nilai dan moral Pancasila kurang mendapat penekanan yang proporsional; (2) secara metodologi, ada kecenderungan pembelajaran yang mengutamakan pengembangan ranah sikap (afektif), ranah pengetahuan (kognitif), sedangkan ranah keterampilan (psikomotorik) belum dikembangkan secara optimal dan utuh (koheren). Dengan ruang lingkup materi pembahasan mengenai Pancasila, sebagai dasar negara, ideologi, dan pandangan hidup bangsa, UUD 1945 sebagai hukum dasar tertulis yang menjadi landasan konstitusional kehidupan bermasyarakat, berbangsa, dan bernegara, Negara Kesatuan Republik Indonesia, sebagai kesepakatan final bentuk Negara Republik Indonesia, Bhinneka Tunggal Ika, sebagai wujud filosofi kesatuan di balik keberagaman kehidupan bermasyarakat, berbangsa, dan bernegara (Santoso et al., 2015). 
Dalam masyarakat multikultural, dibutuhkan adanya sebuah pendidikan yang mampu mengajarkan kepada siswa akan pentingnya nilai-nilai multikultural. Hal ini dipandang penting karena dalam masyarakat multikultural potensinya terjadinya konflik dan gesekan diantara masyarakatnya sangat besar. Sihingga dibutuhkan sebuah usaha kebudayaan berupa pendidikan yang dapat menumbuhkan spirit keberagaman, serta menumbuhkan motivasi hidup bangsanya yang hidua dalam keberagaman dan pluralitas. Pendidikan Kewarganegaraan sebagai pendidikan multikultur adalah sebuah strategi pendidikan yang diaplikasikan dalam proses pembelajaran dengan cara menggunakan perbedaan kultural yang terdapat pada diri siswa, seperti perbedaan etnis, perbedaan agama, perbedaan bahasa, perbedaan jenis kelamin, perbedaan kelas, ras, agar proses pembelajaran menjadi efektif dan sesuai dengan tujuan pmbelajaran. Pelaksanaannya melalui penerapan model dan pendekatan pembelajaran yang mampu membawa siswa memiliki pengalaman belajar khususnya pengalaman untuk menerapkan nilai-nilai multikultural di luar proses pembelajaran.

Pendidikan multikultural sangat penting khususnya dalam pengajaran Pendidikan Pancasila dan Kewarganegaraan. Karena dalam pembelajaran Pendidikan Pancasila dan Kewarganegaraan siswa diajarkan bagaimana menjadi manusia Indonesia yang pancasilais, yang mampu menempatkan diri sebagai seorang individu yang mengerti memahami keberagaman dan pluralitas di Indonesia, dan Pendidikan multikultural sebagai jawaban adalah proses bagaimana penanaman cara hidup untuk menghormati secara tulus, dan toleran dalam keberagaman budaya yang hidup di tengah-tengah masyarakat majemuk bagi bangsa Indonesia khususnya generasi muda. Dengan diberikannya pendidikan multikultural diharapkan adanya kelenturan mental bangsa dalam menghadapi konflik-konflik yang berbau suku antar golongan ras dan agama (SARA), sehingga persatuan bangsa tidak mudah retak dan terjadi disintegrasi bangsa. Keharusan untuk mewujudkan masyarakat Indonedia yang mengerti dan memahami keberagaman ini tidak dapat dilepaskan dari kebutuhan dari warga negara itu sendiri baik secara individu mauun sebagai bagian dari masyarakat.

Pendidikan Kewarganegaraan atau dalam kurikulum 2013 berubah kembali menjadi Pendidikan Pancasila dan Kewarganegaraan berperan sebagai Pendidikan multikultural dalam Undang-Undang Nomor 20 Tahun 2003 tentang Sistem Pendidikan Nasional (Sisdiknas), Pendidikan Pancasila dan Kewarganegaraan merupakan nama mata pelajaran wajib untuk kurikulum pendidikan dasar dan menengah dan mata kuliah wajib untuk kurikulum pendidikan tinggi (Pasal 37). Pada Pasal 37 bagian Penjelasan dari UndangUndang Nomor 20 Tahun 2003 Pendidikan kewarganegaraan dimaksudkan untuk membentuk peserta didik menjadi manusia yang memiliki rasa kebangsaan dan cinta tanah air. Dengan adanya ketentuan UndangUndang Nomor 20 Tahun 2003 tersebut, maka kedudukan pendidikan kewarganegaraan sebagai basis pengembangan masyarakat multikultural dalam sistem pendidikan di Indonesia semakin jelas dan mantap. Penelitian ini didasarkan pada teori bahwa PKn merupakan salah satu ujung tombak dari pendidikan multikultural dalam rangka pembentukan karakter warga negara multikultural yang menghargai identitas budaya masyarakat 
yang plural secara demokratis, dan membentuk mosaik yang indah (cultural pluralism: mozaik analogy) dalam satu semboyan Bhinneka Tunggal Ika (Garcia, 1982, pp. 37-42).

Multikulturalisme merupakan istilah yang digunakan untuk menjelaskan tentang pandangan seseorang tentang keragaman kehidupan di dunia, ataupun kebijakan kebudayaan yang menekankan tentang penerimaan terhadap adanya keragaman, dan berbagai macam budaya (multikultural) yang ada dalam kehidupan masyarakat menyangkut nilai-nilai, sistem, budaya, kebiasaan, dan politik yang mereka percayai. Munculnya Pendidikan multikultural (multicultural education) merupakan merupakan respon adanya kenyataan bahwa Indonesia mempunyai berbagai keragaman di dalam masyarakatnya. Untuk menghadapi tuntutan akan perubahan zaman yang sangat cepat akan multikulrutalisme maka yang dilakukan ialah menyiapkan generasi penerus bangsa Indonesia agar di masa yang akan datang mampu menjadi bangsa yang mapan dalam hal menyikapi multikulrutalisme yang ada di Indonesia. Karena bangsa Indonesia tidak segera menyikapi hal itu, maka bukan tidak mungkin masalah-masalah yang timbul sebagai dampak keberagaman di Indonesia akan semakin muluas, konflik SARA yang pernah melanda Indonesia tidak menutup kemungkinan akan terulang kembali.

Multikulturalisme merupakan sebuah ajaran akan pentingnya menghargai perbedaan dan kesederajatan. Perbedaan individu maupun perbedaan kelompok dilihat sebagai sebuah kekayaan dari perbedaan kebudayaan yang ada. Di dalam perbedaan terdapat kesederajatan, kesederajatan menekankan terutama pada sisi perbedaanperbedaan askriptif, seperti perbedaan suku bangsa dan kebudayaan yang terdapat didalamnya, ciri-ciri fisik dari setiap individu, keyakinan akan nilai-nilai ajaran keagaman, gender, dan perbedaan usia. Multikulturalisme tidah hanya memperjuangkan kesetraan kesukubangsaan dari sebuah kelompok masyarakat, gender, ras, dan usia saja, tetapi lebih dari itu multikulturalisme adalah sebuah perjuangan bagi mereka yang tersisihkan oleh sebuah sistem yang besar yang lebih mengutamakan homogenitas dari suatu kelompok masyarakat yang ada. Selain itu, multikulturalisme juga dapat dipakai secara deskriptif untuk menyebut sebuah tatanan masyarakat yang memiliki keanekaragaman budaya di dalamnya.

Kesadaran tentang pentingnya mempelajari dan menghayati multikulturalisme sudah muncul sejak negara Republik Indonesia terbentuk dan digunakan oleh pendiri bangsa Indonesia. Hal ini dikemukakan oleh Suparlan (Sanaky, 2005, p. 1) bahwa multikulturalisme sudah digunakan untuk mendesain kebudayaan bangsa Indonesia. Tetapi, bagi bangsa Indonesia masa kini konsep multikulturalisme menjadi sebuah konsep baru dan asing. Kesadaran terhadap konsep multikulturalisme yang dibentuk oleh pendidiri bangsa semenjak zaman pra kemerdekaan hilang bagaikan ditelan bumi ketika masa Orde Baru. Kesadaran tersebut dipendam atas nama persatuan dan stabilitas negara yang kemudian muncul paham monokulturalisme yang menjadi tekanan utama dan akhirnya semuanya memaksakan pola "penyeragaman" berbagai aspek, sistem sosial, politik dan budaya, sehingga sampai saat ini wawasan multikulturalisme bangsa Indonesia masih sangat rendah.

Pengembangan kompetensi bagi warga negara yang bercirikan multikultural mutlak dilakukan bahkan telah menjadi bagian tak terpisahkan dalam upaya pengembangan warga negara multikultural. Kompetensi 
kewarganegaraan multikultural adalah seperangkat pengetahuan, nilai, dan sikap, serta keterampilan siswa sebagai warga negara yang mendukung upaya terwujudnya warga negara multikultural yang partisipatif dan bertanggung jawab dalam kehidupan bermasyarakat, berbangsa, serta bernegara.

Kompetensi

multikultural

sebagaimana dikemukakan Branson \& Quigley (1998) yaitu: 1) Civic knowledge (pengetahuan kewarganegaraan), berkenaan dengan konten atau apa yang seharusnya diketahui oleh setiap warga negara; 2) Civic skill (kecakapan kewarganegaraan), adalah kemampuan intelektual dan partisipatif setiap warga negara; dan 3) Civic disposition (watak kewarganegaraan) yang mengisyaratkan pada karakter yang terdapat di dalam diri warga negara yang mendukung bagi pemeliharaan dan pengembangan demokrasi konstitusional Branson (1998, p. 16). Ketiga kompetensi tersebut diolah menjadi sebuah formula yang dimiliki setiap siswa agar mampu menjadi warga negara yang cerdas dan baik, khususnya menjadi warganegara yang mengerti, memahami, serta mampu melaksanakan apayang seharusnya dilakukan oleh seorang warga negara multikulturalisme, dan PPKn menjadi ujung tombak bagi siswa untuk mampu mempelajari multikulturalisme di Indonesia.

Salah satu tujuan sentral pendidikan adalah menpersiapkan peserta didik untuk dapat terlibat baik langsung maupun tidak langsung dalam tema-tema dialog yang berkaitan dengan nilai, adat, kebiasaan, sosialisasi, enkulturasi, kolonialisme, praktik hak asasi, kedudukan perempuan, keluarga, revolusi industri, kelas sosial, perang saudara, keragaman etnis, dan tema lainnya yang berkaitan dengan kehidupan warga negara sebagai individu maupun sebagai masyarakat.
Selanjutnya untuk memperdalam pemahaman siswa guru harus mampu membawa siswa untuk bisa menghargai kompleksitas atau keberagaman dari kebenaran penafsiran yang tidak mampu disederhanakan. Untuk itu Pendidikan Kewarganegaraan seudah sepantasnya menjadi salah satu mata pelajaran yang mampu mengemban tugas tersebut sebagai mata pelajaran yang di dalamnya trdapat muatan ataupun konten multikulturalisme, karena Pendidikan Kewarganegaraan khususnya di Indonesia mengajarkan bagaimana seorang warga negara untuk mampu menjadi individu yang memiliki kecerdasan dan berkarater baik sesuai dengan nilai-nilai pancasila.

\section{Simpulan}

Pertama, PPKn di Indonesia memiliki makna filosofis dalam mempersiapkan warga negara yang beradap dan bijaksana, hal ini dikarenakan dalam kurikulum PPKn dalam perkembangannya sendiri memiliki makna filosofis pelbagai penentu watak warganegara yang taat hukum yang seimbang antara hak dan kewajiban, sebagai pembentuk nilai, moral dan akhlak bangsa dalam mempersiapkan mental multikultural warga negara.

Kedua, perkembangan kurikulum PPKn di Indonesia berkembang secara dinamis disesuaikan dengan kebutuhan serta visi-misi dari pemerintah yang mempengaruhi dalam pembentukan kebijakan kurikulum pendidikan di Indonesia. Tetapi dalam pelaksanaannya terdapat kekuatan yang menjadi fondasi dalam pelaksanaan mata pelajaran Pendidikan Pancasila dan Kewarganegaraan, yaitu Pancasila, UndangUndang Dasar Negara Republik Indonesia Tahun 1945, politik, hukum, nilai, moral, kearifan lokal, dan kebhinekaan dalam berkebudayaan.

\section{Daftar Pustaka}

Branson, M. S., \& Quigley, C. N. (1998). The 
role of civic education. Washinton DC.

Budimansyah, D. (2010). Penguatan pendidikan kewarganegaraan untuk membangun karakter bangsa. Bandung: Widya Aksara Press.

Budimansyah, D., \& Suryadi, K. (2008). PKN dan masyarakat multikultural. Bandung: Program Studi Pendidikan Kewarganegaraan Sekolah Pascasarjana Universitas Pendidikan Indonesia.

Departemen Pertahanan. (2008). Buku putih pertahanan Indonesia. Jakarta: Departemen Petahanan Republik Indonesia. https://doi.org/075-12-015-1

Garcia, R. L. (1982). Teaching in a pluralistic society: concepts, models. Michigan: Harper \& Row.

Kementerian Pertahanan. (2015). Buku putih pertahanan Indonesia (3rd ed.). Jakarta: Kementerian Pertahanan Republik Indonesia.

Madjid, A. (2014). Implementasi kurikulum 2013 kajian teoritis dan praktis. Bandung: Interes Media.

Miles, M. B., \& Huberman, A. M. (1992). Analisis data kualitatif: buku sumber tentang metode-metode baru. Jakarta: Universitas Indonesia Press.

Sanaky, H. (2005). Sakral (sacred) dan profan: studi pemikiran Emile Durkheim tentang sosiologi agama. Yogyakarta.

Santoso, G., Al Muchtar, S., \& Abdulkarim, A. (2015). Analysis SWOT Civic Education curriculum for senior high school year 1975-2013. CIVICUS: JURNAL PENDIDIKAN KEWARGANEGARAAN, 19(1).

Setiawati, W. (2016). Implementasi penilaian keterampilan kewarganegaraan berdasarkan Kurikulum 2013. CIVICUS: JURNAL PENDIDIKAN KEWARGANEGARAAN, 20(2), 69-79.

Somantri, N. (1969). Pelajaran kewargaan negara di sekolah. Bandung: IKIP Bandung.

Tempo. (2016). Kerusuhan di Tanjung Balai, ini versi Polda Sumatera Utara. Retrieved from https://nasional.tempo.co/read/791902/k erusuhan-di-tanjung-balai-ini-versipolda-sumatera-utara
Winataputra, U. S. (2012). Pendidikan kewarganegaraan dalam perspektif pendidikan untuk mencerdaskan kehidupan bangsa: gagasan, instrumentasi, dan praksis. Bandung: Widya Aksara Press. 